LAW, ETHICS AND MEDICINE

\title{
Are patents for methods of medical treatment contrary to the ordre public and morality or "generally inconvenient"?
}

\author{
O Mitnovetski, D Nicol
}

J Med Ethics 2004;30:470-477

"No one has advanced a just and logical reason why reward for service to the public should be extended to the inventor of a mechanical toy and denied to the genius whose patience, foresight, and effort have given a valuable new [discovery] to mankind" (Katopis CJ. Patents v

patents: policy implications of recent patent legislation. St John's Law Review 1997;71:329). The law around the world permits the granting of patents for drugs, medical devices, and cosmetic treatment of the human body. At the same time, patentability for a method of treatment of the same body is denied in some countries on various public policy grounds. Is there any logical justification for this distinction? Are methods of medical treatment not as vital to the health or even to the life of a patient as drugs or medical devices? Why is a cosmetic result patentable and a curative result not?

See end of article for authors' affiliations

\section{Correspondence to:} O Mitnovetski, Allens Arthur Robinson, Stock Exchange Centre, 530 Collins Street, Melbourne Vic 3000, Australia; Oksana.Mitnovetski@aar. com.au

Received 13 June 2002 Revised version received 11 September 2002 Accepted for publication 26 September 2002
$\mathrm{P}$ atent legislation gives legal protection to new inventions, once they have been patented by their owners. A patent is a temporary monopoly granted to the owner in return for disclosure of the invention to the public. ${ }^{1-3}$ Both society and the inventor benefit from the patent system. The inventor benefits by being able to exclude others from exploiting the invention for 20 years, and the public benefits because when the patent expires, the invention is freely available for others to use.

Patenting of methods of medical treatment of human beings is, however, a complicated issue for it is not only based on patent law but also on medical law. Medical law has its origins in the Hippocratic Oath, and the goal is the preservation of human life. Since the goal of patent law is to encourage innovation by rewarding inventors, it is quite distinct from the goal of medical law. Thus, there is a public policy concern that in order to ensure the best possible health treatment, physicians must always be free in their choice of treatment. ${ }^{4}$ It must be also noted that in the most recent Australian case, Bristol Myers Squibb Co v F H Faulding \& Co Ltd, Finkelstein J clarified that the "ethical grounds" should be understood as references to "public policy grounds". ${ }^{5}$ Since a patent may restrict this freedom, it has been argued that methods of medical treatment should be excluded from patent protection.

Approximately 80 countries around the globe prohibit methods of medical treatment from being granted patent protection. The list includes all European countries and countries in Asia, Africa, North America, South America, and Central America. Patent protection is, however, available in other countries. In the United States-for example, methods of medical treatment have been considered patentable since 1954, when the case Ex parte Scerer ${ }^{6}$ overruled Ex parte Brinkerhoff $24 .^{7}$ Similarly, in Australia patents have been available for this type of subject matter since 1972, following the High Court decision in Joos $v$ The Commissioner of Patents and decisions of two Federal Court cases.5 89 Since 1976, novel therapeutical applications have been patentable in Japan. In New Zealand the situation is not clear, although in some circumstances new medical uses of known pharmaceutical substances will be patentable. ${ }^{10} 11$

This article examines Australian patent law, the law of other countries and the public policy considerations surrounding this matter. It concludes that public policy considerations do not provide sufficient basis to justify a discrimination against patenting of methods of medical treatment. The authors suggest that medical treatment patents are not contrary to the ordre public and morality (this terminology comes from the international Agreement on Trade Related Aspects of Intellectual Property Rights 1995, ${ }^{1}$ article 27) or "generally inconvenient" (from section six of the Imperial Statute of Monopolies $1623,{ }^{12}$ and therefore ought to be granted. $†$

\section{THE PATENT SYSTEM ORIGINS}

The very first monopolies appeared about 500 BC according to Phylarchus, who was quoted in the third century $\mathrm{AD}$ by Athenaeus in the Banquet of the Learned $^{13}$ and the first letters of patent were granted in 1440 to John of Shiedame who introduced a method of manufacturing salt on a scale never before attempted in England (Bristol Myers Squibb Co v F H Faulding Co Ltd, ${ }^{5}$ p 587). While originally designed to encourage the setting up of new industries, the monopoly system began to be abused by the Crown, in particularly by Elizabeth I. It led to section six of the Statute of Monopolies in 1623, which declared all monopolies void except those that are manners of manufacture, but only in so far as

†ln this article, the terms "morality" and "ethics" are used as defined by The Oxford English Dictionary. The term "ordre public", derived from French law, is not easy to translate into English, and therefore the original French term is used in the TRIPS agreement. It expresses concerns about matters threatening the social structures which tie a society together. 
they are: "not contrary to the law or mischievous to the state, by raising prices of commodities at home, or hurt of trade, or generally inconvenient". ${ }^{12}$ Section six was destined to become the foundation of the patent law not only in England, but also throughout the world. The requirement that there be a "manner of manufacture" in the Statute of Monopolies has been described as "the touchstone of patentability"14 and still is in force today in Australia, New Zealand, and Israel (Patents Act 1990 (Cth), ${ }^{3}$ S 18 and schedule 1).

\section{THE DEVELOPMENT OF THE EXCLUSION OF METHODS OF MEDICAL TREATMENT The United Kingdom}

Methods of medical treatment have long been excluded from patenting in the UK. The exclusion can be traced back to the 1914 case of In the Matter of $C \& W^{\prime}$ s Application for a Patent.$^{15}$ In this case, the solicitor general refused an application for patent protection for a process of extracting toxic lead from living human beings upon the ground that the alleged invention related simply to a medical treatment. The basis for such refusal was that a medical treatment process did not employ any form of manufacture or of trade, thus lacking commercial value (In the Matter of $C \& W$ 's Application for a Patent, ${ }^{15} \mathrm{p} 236$ ).

Since that decision, for many years it was accepted as axiomatic that there could be no patents for medical treatment, because they do not result in, or in the improvement of, a "vendible product", ${ }^{16}$ a product that can be sold.

In 1959, the Australian High Court handed down its famous landmark decision in the National Research Development Corporation $v$ Commissioner of Patents $(N R D C),{ }^{17}$ that for a method to be patentable it does not necessarily have to result in the making of a "vendible product", provided that it has value in the field of economic endeavour. The court noted in passing that the exclusion of methods of medical treatment may lie outside the concept of invention because they are "essentially non economic" (NRDC, $\left.{ }^{17} \mathrm{p} 275\right)$. Given the new formulation of the "manner of manufacture" test in NRDC, however, and the growing economic importance of medical treatments, it has been widely accepted that this rationale for exclusion lacks foundation. As the exclusion of such methods had become established practice, the courts in the UK "grasped" for some other ground on which to base their refusal (as noted by Davidson CJ in Wellcome Foundation $v$ Commissioner for Patents). ${ }^{18}$

In Eli Lilly \& Company's Application-for example, ${ }^{19}$ the court clearly stated that the restriction still applied regardless of other changes in law (associated with $N R D C^{17}$ ) and refused a patent application, for the first time, on the basis of the public policy proviso to section six of the Statute of Monopolies. In that case the applicant discovered that certain chemical compounds which were already known had unsuspected anti-inflammatory properties that could be used in the symptomatic treatment of various inflammatory conditions present in humans and animals. The court confirmed that the law at that time stood so that no patent could be granted for a new method that claimed to be a cure or prevention of disease in human beings. The authority for such a decision was the earlier decision in Schering's Application in 1971. ${ }^{20}$ The court acknowledged that the prohibition was "technically anomalous and therefore illogical" stating "the reasons for such an exclusion appear to us to be based in ethics rather than logic..." (Eli Lilly and Company's Application 1975, ${ }^{19} \mathrm{pp}$ 444-5). The court decided that, although the "generally inconvenient" exception in the Statute of Monopolies was never used before as the basis for refusals of medical treatment applications, it "can no more be ignored" Eli Lilly and Company's Application, $\left.{ }^{19} \mathrm{p} 445\right)$.
It must also be noted that in the 1970s the United Kingdom had an opportunity to change its attitude toward patentability of medical treatment when the Banks committee reviewed the British patent system. ${ }^{21}$ The committee considered a wide range of issues, including the question of the patentability of a process consisting of using known compound for treating human beings medically. Despite being aware of representations made by the English courts that the legislature should review the question whether applications for patents for medical treatment should be permitted,$^{20}$ the committee decided this was not desirable. No explanations were given for this decision. The committee has been criticised for simply following established practice of refusing such patents, without forming its own opinion. ${ }^{22}$ As a consequence of the Banks committee's report, methods of medical treatment were expressly excluded by the parliament of the United Kingdom in section 4(2) of the new legislation (Patents Act 1977 (UK), ${ }^{2}$ S 4(2)). The authors believe that but for the report, the parliament might have changed its attitude toward patentability of medical treatments. Moreover, the report played a significant role in the development of the exclusion of medical treatment patents in article 52(4) of the European Patent Convention (EPC). ${ }^{23}$

\section{The European Patent Convention}

The European Patent Convention was negotiated by a group of European countries in the early 1970s with the aim of creating uniform European law. Though the patent courts of other European countries had not dealt so extensively with the issue of patentability of methods of medical treatment as the courts in the United Kingdom, the general practice was similar. ${ }^{24}$ A grant for patent protection in France and Italyfor example, would be denied if the alleged invention were lacking in industrial character (Whitford $\mathrm{J}$ in Schering's Application, ${ }^{20} \mathrm{p}$ 27). In Austria ${ }^{25}$ and Switzerland ${ }^{26} 27$ one of the grounds for refusal of medical invention was an ethical consideration. In fact, up until 1974 there had been no court decision in any of the member states of the EPC that had upheld a claim related to a method of medical treatment. In the early 1900s, the German Patent Office granted a few patents for medical methods, including a method of removing deeper stitches from wounds (German patent no 150666); a method for treating curvature of the human spine (German patent no 150699); a method of removing magnetised objects from the eye or another part of the body (German patent 155294), and a method of transilluminating parts of the body using $\chi$ rays (German patent 156389).

In the 1904 case of Badewasser, ${ }^{28}$ however, the German Patent Office changed its attitude towards patentability of medical inventions, stating that the treatment of humans was an area for which patent protection had not been created by the legislature. The case established a precedent for future cases, that an industrially applicable invention could only be assumed to exist if raw material was mechanically or chemically treated or processed, as demonstrated in a later decision of the federal Supreme Court of September 26, 1967. ${ }^{29}$

In this climate, the EPC was signed in Munich in 1973 and came into effect in 1978. Article 52(4) expressly excludes "methods of medical treatment of the human or animal body by surgery or therapy, and diagnostic methods practised on the human or animal body" from patentability, as being not "susceptible of industrial application. ${ }^{23}$ Shortly after signing the EPC, the member states began adjusting their legal systems to accord with European uniform law, and article 52(4) was largely adopted. The United Kingdom, Germany, and France-for example, included mirror provisions, declaring such methods as not industrially applicable. ${ }^{20} 31$ Denmark, Italy, and Sweden treat them as non-inventions, and Switzerland treats them as legal exceptions to patenting. ${ }^{32-35}$ 
Without question, the EPC was formulated as a compromise between the member states. Arguably, the case law of the states did not provide clear justification for exclusion from patent protection of methods of medical treatment. Thus it could be viewed that such exclusion was a product of political pressure to treat them as being contrary to ordre public and morality. $\neq$

\section{The "legal fiction" of the Swiss type claims}

Even though it seems that article 52(4) EPC left no hope for inventors of medical treatments to obtain patent protection for their inventions, the courts have decided that new types of claims, directed to the "use of compound $\mathrm{X}$ in the manufacture of a medicament for a new therapeutic use", are outside of the exclusion. These claims are known as "Swiss type claims" and are also referred to as "second medical use". They have been developed as a result of the interpretation of article 54(5) EPC and the pharmaceutical industry's pressure to provide protection for second and further medical uses. ${ }^{36}$

The need for additional patent protection arises when a drug is already known for one or more therapeutic applications, and another, unexpected discovery is made about the curative property of that drug. It is well known-for example, that aspirin is used for its anti-inflammatory property in treating humans. Take a newly discovered use for aspirin, namely its use as a prophylactic of strokes. The question arises: "can a newly discovered second use for aspirin be patentable?" The answer will be: "no" for the following reasons. Since the chemical compounds were already known, the only possible claim is to a new manner of use. Such new manner of use is, however, directed to treat a disease in human beings, thus it is a method of therapeutic treatment and excluded under article 52(4) EPC. In order to avoid this exclusion, the claim format must be redrafted in the Swiss type format: "use of aspirin for the manufacture of a medicament for the prophylaxis of strokes". The word "manufacture" inserts into the claim the element of "industrial application" required by article 52(4), and thus secures protection for use of the known compound in the preparation of a medicament for the new medical use. A good example of this Swiss type claiming is seen in the New Zealand case of Pharmaceutical Management Agency Ltd $v$ Commissioner of Patents. ${ }^{11}$

Clearly, the Swiss type claim is a way around article 52(4) EPC and therefore is an indirect way to get patent protection for methods of medical treatment that involve the new medical use of drugs. In consequence, only "pure methods" or "surgical procedures" are left unpatentable, and, in the authors' view, the exclusion in article 52(4) EPC carries little weight. If methods of medical treatment inventions were meant to be excluded from patentability by the EPC, they should have been excluded as "exceptions to patentability" under article 53 EPC, as in section 2(b) of the Swiss Patent Act. ${ }^{35}$

\section{DEPARTURE FROM THE EXCLUSION \\ Australia}

Like English patent law prior to the 1977 Patents Act (UK), Australian patent law does not expressly prohibit patenting of methods of medical treatment and the issue has been left to the courts to determine. Despite similarities in the law with the UK, however, and early opposition to the patenting of methods of medical treatment by the Australian courts and Patent Office, both have departed from this long established view and lean towards patentability of such methods. Since

$\$$ Note that article 53(a) EPC also expressly excludes patenting of inventions where their publication or exploitation would be contrary to ordre public and morality. the High Court decision in Joos $v$ The Commissioner of Patents in 1972, which was concerned with the cosmetic method of treating baldness with a hair weaving technique, grants of patent have been available for methods of medical treatment. $^{8}$

The Patents Act 1990 (Cth) defines an "invention" as:

[a]ny manner of new manufacture the subject of letters patent and grant of privilege within section six of the Statute of Monopolies, and includes an alleged invention" (Patents Act, ${ }^{3}$ schedule 1).

Since the entirety of section six of the Statute of Monopolies is incorporated into the definition of invention, Australian courts are empowered to consider whether the patenting of an alleged invention is "generally inconvenient". The opponents to the patentability of methods of medical treatment rely on that proviso, arguing that granting a patent to such a method is "generally inconvenient".

The first time a court had to decide whether this argument was correct was in the Federal Court case, Anaesthetic Supplies Pty Ltd $v$ Rescare Ltd (Rescare), ${ }^{9}$ which concerned a device for treating snoring sickness and a method for its treatment. At first instance, Gummow J held that it was not generally inconvenient that such an invention be granted patent protection. ${ }^{37}$ His Honour stated that it would be an illogical result if products for treatment of the human body were patentable and methods of treating were not.

On appeal, two of the judges of the Full Court of the Federal Court followed Gummow J's reasoning, that methods of medical treatment were patentable under Australian law. ${ }^{5}$ Lockhart J (with whom Wilcox J generally agreed) commented that there was no statutory provision in Australia prohibiting the grant of a patent for a process of medical treatment of humans. His honour noted that the parliament had the opportunity to exclude such methods when it enacted the 1990 act, but the limit of the exclusion was section 18(2): "Human beings and biological processes for their generation, are not patentable inventions" (Bristol Myers Squibb Co v Faulding \& Co Ltd 2000, ${ }^{5}$ p 19).

Sheppard J strongly dissented, arguing that granting a patent for a method of medical treatment would be "generally inconvenient" within the public policy proviso of section six of the Statute of Monopolies. The arguments delivered by Sheppard J will be debated in the following part of this article.

Following Rescare, methods of medical treatment were frequently granted. Then, in the 1998 case of Bristol Myers Squibb Co v F H Faulding \& Co Ltd ${ }^{38}$ the issue was raised again in a case involving two patents for a method of administering the drug Taxol in the treatment of cancer. Heerey $\mathrm{J}$ of the Federal Court of Australia did not feel bound by the decision in the Rescare case, considering it not to be ratio decidendi (a binding precedent) but simply an obiter (a statement that is not binding). Heerey J agreed with Sheppard J in Rescare and followed his dissenting judgment. As a result, the patenting of the method in the issue was considered to be "generally inconvenient" for public policy reasons and the two patents were held to be invalid. On appeal, however, the Full Court unanimously overturned Heerey's judgment by following the majority decision in Rescare that patentability of methods of medical treatment was not "generally inconvenient" $t^{\text {s. }}$

\section{THE CASE FOR PATENTABILITY OF MEDICAL TREATMENT}

The Bristol Myers case has reopened the debate in Australian society concerning the important question: "is it generally inconvenient to patent a method of medical treatment"? 
Eight members of the federal court of Australia gave very close attention to it, and six of them concluded that it was not. These members were: Gummow, Lockhart, Wilcox, Lehane, Finkelstein JJ, and Black CJ. It could be concluded, then, that the question of whether methods of medical treatment are patentable in Australia has fully been answered, and answered in the affirmative. The concern is, however, whether the approach taken by the courts is appropriate, and if it is not, whether the legislature should interfere and expressly exclude such methods from patenting, following the European approach.

Are patents of methods of medical treatment "generally inconvenient" or contrary to the ordre public and morality? In order to answer this question it is necessary to focus on the public policy considerations and the impact of the patents of medical treatment on the medical profession and the society as a whole.

\section{Dissemination of information}

One concern is that medical method patents may restrict dissemination of information. Since a patent takes several years to issue, the publication of details of the invention is delayed. The free flow of information through publication in medical journals, textbooks, and seminars is the accepted form of dissemination, ${ }^{39}{ }^{40}$ but inventors have to be careful not to disclose their inventions prior to filing patents, because this will jeopardise the requirement of "novelty".

It is well known that the progress of medicine depends on the dissemination of ideas. It is not always recognised, however, that one of the important features of patent law is that it actually facilitates dissemination of information. Inventors share their ideas in return for the grant of patents. Patent law is designed to reward the inventor, not merely for inventing something, but also for disclosing the invention to society. Therefore, patent law around the world requires the inventor to fully describe the invention and explain the best method of making and using it in such full, clear, and succinct terms as to enable any person skilled in the art to use it. In Australia-for example, this requirement is expressed in section 40 of the (Patents Act 1990, ${ }^{3}$ S40). The patent specification can be treated as a recipe or formula to copy a patented method. Medical journals, on the other hand, do not have such strict requirements to provide a clear and succinct recipe for a discovered method. Moreover, delays associated with the submission, review, and publication of articles may not be significantly different from the delay in publication of patents. Patent Convention Treaty applications are required to be published 18 months after filing, ${ }^{41}$ and in some countries inventors are required to publish immediately after filing (EPC, ${ }^{23}$ article 54(2)) ${ }^{42}$

It is also noteworthy that the developing academic culture of patenting does not significantly differ from the established academic culture of publishing, since both are now taken into account in recognising academic achievement.

The alternative to patent protection is secrecy. In the absence of patent protection the inventors may choose to keep their inventions secret to prevent copying by others, at little cost or effort and with the expectation of high reward. Secrecy will inevitably slow dissemination of information far more than patenting.

\section{Conflict of interest}

Another fear of opponents of medical methods patents is the possibility of conflict of interest. This is based on the argument that if physicians have paid licence fees (licensed physicians) to enable them to use a patented method this may affect their discretion when choosing the correct treatment. It has been argued that it would be in the physician's financial interest to recommend the method that he/she is licensed to perform (the licensed method) over others in order to recoup the costs of licensing. ${ }^{43}$ Alternatively, an unlicensed physician may avoid supplying a patient with the best available method in order to avoid licence fees. ${ }^{44}$

This argument ignores the fact that physicians have a duty to inform the patient of all treatment alternatives. A related conflict between a physician's research directed toward a patent and patient's right to know the physician's motives was at issue in Moore $v$ Regents of University of California. ${ }^{45}$ Moreover, medical malpractice laws and fiduciary and ethical duties are powerful deterrents against performing unnecessary medical procedures or not acting in the patient's best interest.

In order to ensure physicians provide the best treatment available, it has been suggested that instead of asking for a set licence fee regardless of the number of procedures performed, the patent holder should ask for a small royalty per procedure. ${ }^{46}$ Dr Pallin-for example, a former holder of an American patent concerning a new method of cataract surgery, proposed a licensing scheme consisting of a $\$ 5$ royalty per surgery. ${ }^{43}$ Accordingly, this scheme would not give the licensed physician a financial incentive to recommend a licensed method if it is not needed. Moreover, it means that physicians will not be faced with payments of upfront licence fees.

\section{Harm to the physician/patient relationship}

Another argument involves a patient's expectation of privacy in his/her relationship with a physician. The concern is that an infringement lawsuit may invade a patient's right to privacy, as a patentee may be entitled to access medical records. ${ }^{47}$ In some instances, however, including inquiries about compliance with government health care provisions, requirements of detailed disclosure of a patient's medical conditions by an insurance company and emergency medical situations, authorities already have access to medical records. In all such cases an obligation of confidentiality can be imposed on the other party. Furthermore, the other party is not allowed to use this information in relation to other lawsuits.

\section{Increasing health care cost}

Another fear of opponents of medical methods patents is that they will drive up the already high cost of health care. ${ }^{48}$ Drugs and devices, however, play a significant role in increasing health care costs yet have enjoyed patent protection for many years. Moreover, investment in expensive new treatment may result in reduced health care costs in the long term, because of shortened hospital stays, less intensive care, and general efficiency. ${ }^{49}$ Thus, a patented method can be cheaper than the unpatented one.

\section{Reluctance to perform a patented method for fear of infringement}

One of the most significant concerns raised by opponents of medical methods patents is the fear of infringement, particularly related to emergency procedures. There are, however, many other restraints on the physician's practice. Insurance, medical malpractice actions, and the issue of obtaining consent of minor or incompetent patients impact significantly on the physician's practice. Consequently, physicians may be reluctant to perform a method on a patient, regardless of whether this method is patented or not.

Additionally, the existing equitable doctrine of necessity would protect physicians who used a patented medical procedure in an emergency. It is hard to imagine a physician who would refuse to provide an emergency procedure because of fear of infringement. Moreover, it is highly unlikely that anyone would seek to patent an emergency procedure in the first place, knowing that it will be 
unenforceable because of the doctrine of necessity. The point is with patentability of non emergency procedures, by itself, the "fear of infringement" argument carries little weight.

\section{Consistency and logic of the law}

There has been a long practice of giving a patent protection for drugs, medical devices, and cosmetic treatment of the human body and such patents are not considered to be contrary to the ordre public and morality or "generally inconvenient". Why should patent protection for methods be? If-for example, the drug for treating cancer is patentable, what is the justification for refusal to patent a method for administering this drug to a patient? Similarly, in the case of the treatment of blood by dialysis, according to article 52(4) of the EPC, such methods will be excluded from patentability. ${ }^{23}$ At the same time, an apparatus for purifying blood will be patentable (provided that it fulfils the standard patenting criteria). Are cancer drugs or the apparatus for dialysis not as vital to the health or even to the life of a patient as methods of their use?

Similarly, when a method of treatment displays both a therapeutic and cosmetic effect, according to the EPC, only a claim to the non-therapeutic effect will be patentable. ${ }^{50}$ Thus, when the description of the claim shows-for example, an antibacterial activity and a comedolytic one, the first will be excluded from patentability by article 52(4) EPC, but the second will not. ${ }^{51}$ It is our view that this distinction is clearly artificial, because in some circumstances, a cosmetic treatment will also be therapeutic. A face lifting procedure (which is clearly cosmetic) - for example, might have a therapeutic impact on the patient's psychological wellbeing; similarly, a treatment of comedomiform acne, to be effective, must have both cosmetic and therapeutic approaches.

The matter has been put in this way:

\section{Is there any justification in law or in logic to say that simply because, on the one hand, substances produce a cosmetic result or a functional result as opposed to a curative result, the one is patentable and the other is not? I think not. The court must now take a realistic view of this matter in the light of current scientific developments and legal progress. The law must meet the needs of the age (Wellcome Foundation $v$ Commissioner of Patents ${ }^{17}$ per Davison CJ p 621).}

Thus these distinctions have been viewed as "distinctions without a difference" (Wellcome Foundation v Commissioner of Patents $1959^{17}$ per Davison CJ p 621).

\section{CONCLUSION}

Public policy considerations do not provide a sufficient basis to justify discrimination against patenting of methods of medical treatment. Such inventions bring potential relief to numerous sufferers, thus cannot be viewed to be contrary to the ordre public and morality or "generally inconvenient". They are as worthy of patent protection as many other kinds of inventions such as drugs, medical devices, and cosmetic treatment. Indeed, every argument raised against methods of medical treatment patents could be equally raised against patents for drugs, medical devices, and cosmetic treatment.

The patenting of medical treatment advances medical knowledge by encouraging the development of new medicines and surgical methods, which in turn increases the public good and, in particular, the quality of the community's health care. The authors believe that the arguable negative effects of such patenting do not outweigh the benefits derived from it, as the patenting of such treatment does not decrease the availability of health care and does not create new obstacles different from those already existing in the medical world.

Furthermore, in some instances, the availability of patent protection may be the only way to attract investment in costly clinical trials. In this situation, the availability of a patent becomes an incentive to invest in medical research, and, therefore, a condition for the very existence of the method itself. Consequently, a paradox arises: without a monopoly on a method of medical treatment there may be no method. ${ }^{52}$ While there is no empirical data to prove either of the competing policies, the authors believe that prohibition of medical methods patents may well discourage innovation. On this basis, there are strong ordre public and morality reasons and "generally convenient" reasons to justify the existence of such patents.

\section{Authors' affiliations}

O Mitnovetski, Allens Arthur Robinson, Stock Exchange Centre, Melbourne, Victoria, Australia

D Nicol, Faculty of Law, University of Tasmania, Hobart, Australia

The authors request any comments or opinions that readers may have on the issues they have raised. These should be directed to O Mitnovetski: Oksana.Mitnovetski@aar.com.au

\section{REFERENCES}

1 Agreement on Trade Related Aspects of Intellectual Property Rights Act, 1995 (TRIPS). London: The Stationery Office, 1995, articles 27 and 33.

2 Patents Act 1977 (UK). London: HMSO, 1977, S 25.

3 Patents Act 1990 (Cth). Canberra: Australian Government Publishing Service, 1991 , Ss 65 and 67.

4 Pila J. Methods of medical treatment within Australian and United Kingdom patents law. Univ NSW Law J 2001;24:420-61.

5 Bristol Myers Squibb Co v F H Faulding \& Co Ltd (2000) :46 IPR 553586.

6 Ex parte Scerer 103 USPQ (BNA) 107 (1954).

7 Ex parte Brinkerhoff 24. Off Gaz pat 349 (Comm'r pat off 1883).

8 Joos v The Commissioner of Patents (1972) 126 CLR 611.

9 Anaesthetic Supplies Pty Ltd v Rescare Ltd (1994) 50 FCR 1

10 Wellcome Foundation Ltd v Commissioner of Patents [1983] NZLR 385.

11 Pharmaceutical Management Agency Ltd v Commissioner of Patents [2000] 2 NZLR 529

12 English Statute of Monopolies of 1623, $21 \mathrm{Jac} \mathrm{I,} \mathrm{c} \mathrm{3:} \mathrm{S} 6 \mathrm{http}: / /$ www.ipmall.info/hosted_resorces/lipa/patents/English_Statute1623.pdf (accessed 1 Jun 2004).

13 Athenaeus. Banquet of the learned. London: Henry G Bohn, 1854

14 Industrial Property Advisory Committee. Patents, innovation, and competition in Australia. Canberra: Patent Office, 1994, 39-41 at 41

15 In the Matter of C \& W's Application for a Patent :31 RPC 235. (1914).

$16 \operatorname{Re}$ GEC's Application (1942) 60 RPC 1, per Morton J at 4.

17 National Research Development Corporation v Commissioner of Patents :102 CLR 252. (1959).

18 Wellcome Foundation v Commissioner of Patents [1979] 2 NZLR 591620.

19 Eli Lilly \& Company's Application [1975] :RPC 438.

20 Schering's Application [1971] RPC 337.

21 Banks Committee. The report of the committee to examine the patents system (Banks committee report). London: HMSO, 1970 (Cmnd 4407, paras 23740)

22 White W. Patentability of medical treatment-Wellcome Foundation's (Hitching's) Application. Eur Intellect Prop Rev 1980;2:364-9.

23 European Patent Convention. Munich: 1973: article 52(4).

24 Moufang R. Methods of medical treatment under patent law. IIC 1993;24:18-26.

25 Decision of the Appeal Board of the Austrian Patent Office of May 29, 1973 (1974) GRUR Int 180.

26 Decision of the Swiss Federal Court, September 24, 1946. 72 BGE 1, (1951) GRUR 283.

27 Decision of the Swiss Federal Court, February 24, 1975. 101 BGE 1b 18, (1975) SchwPMMBI. 133, 1975 GRUR Int 314.

28 Badewasser (1904) BlfPNZ 4.

29 BGHZ 313, (1968) GRUR 142

30 Patent Law l, (December 16, 1980, as last amended by the laws of July 16 and August 6, 1998): S 5(2). English version: http://clea.wipo.int/clea/ lpext.dll?f = templates\&fn = main-h.htm\&2.0 (accessed 2 Jun 2004).

31 Intellectual Property Code, (Law No 92-597 of July 1, 1992, as last amended by Law No 96-1106 of December 18, 1996): article L611-16. English version:http://clea.wipo.int/clea/lpext.dll?f= templates\&fn-main-h.htm\&2.0 (accessed 2 Jun 2004).

32 Consolidated Patents Act, (No 824 of 1996): S 1(3). English version: http:// clea.wipo.int/clea/lpext.dll?f = templates\&fn-main-h.htm\&2.0 laccessed 2 Jun 2004).

33 Law on Patents for Invention, (Royal Decree No 1127 of June 29, 1939, as last amended by Legislative Decree No 198 of March 19, 1996): article 12. 
English version:http://clea.wipo.int/clea/lpext.dlllff= templates\&fn-mainhtm\&2.0 (accessed 2 Jun 2004).

34 Patents Act (Act No 837 of 1967, as last amended by Act No 1406 of 1993): $\mathrm{S} 1$. English version http://clea.wipo.int/clea/lpext.dll? $\mathrm{f}=$ templates\&fnmain-htm\&2.0 (accessed 2 Jun 2004).

35 Federal Law on Patents for Inventions (LBI) (June 25, 1954, as last amended March 24, 1995); article 2. English version http://clea.wipo.int/clea/ lpext.dll?f = templates\&fn-main-htm\&2.0 (accessed 2 Jun 2004).

36 Eisai/Second Medical Indication (1985)OJ EPO 60.

37 Rescare Lt v Anaesthetic Supplies Pty Ltd (1992) 111 ALR 205.

38 Bristol Myers Squibb Co v F H Faulding \& Co Ltd (1998) 41 IPR 467.

39 Yang W. Patent policy and medical procedure patents: the case for statutory exclusion from patentability. BUJSCI \& Tech L 1995; 1: $1-29$ at 5 .

40 Loughlan P. Of patents and patients: new monopolies in medical methods. AIPJ 1995;5: 1-15at 13 .

41 Patent Convention Treaty (PCT) Washington, 1970: article 21(2)(a).

42 USC S101 1994:(US).

43 McCoy T. Biomedical process patents. J Leg Med 1992;13:501-19.

44 Meier B. The new patent infringement liability exception for medical procedures. J Legis 1997;23:265-7.

45 Moore v Regents of University of California 1990;793:P2d 479 (1990)

46 Chartrand S. Why is this surgeon suing? Doctors split over patenting of their techniques. New York Times 1995 Jun 8:D1.

47 Garris J. The case for patenting medical procedures. Am $J$ and Med 1996;22:85-93.

48 Gocyk-Farber B. Patenting medical procedures: a search for a compromise between ethics and economics. Cardozo Law Rev 1997:18:1527-46.

49 Anderson S. A right without a remedy: the unenforceable medical procedure patent. Marq Intell Prop L Rev 1999;3:117-53.

50 T 144/83 1986) OJ EPO 301, point 4.

$51 T 36 / 83(, 1986)$ OJ EPO 295.

52 Burch G. Ethical considerations in the patenting of medical processes. Tex Law $\operatorname{Rev} 1987 ; 65: 1139-40$.

\section{COMMENTARY}

Mitnovetski and Nicol provide a stimulating and thorough discussion of patenting of medical methods of treatmentan area of law that interests patent lawyers, medical practitioners, and the public. However, a consideration of alternative perspectives to their account of the exclusion of medical methods of treatment from patentability undermines the rhetorical force of their conclusion that there are "strong ordre public and morality reasons and "generally convenient" reasons to justify the existence of such patents". I set out below four counter arguments to their claims that could lead to a more balanced consideration of whether medical methods should be patented.

\section{TWO EXAMPLES}

Firstly, the patentability of medical methods of treatment cannot be discussed in isolation from the larger current normative debate about the justice of patenting medical technologies. Although much of what the authors discuss is necessarily speculative because it involves patenting inventions that have not previously been patentable, two cases present concrete instances of the impact of granting patent rights on healthcare. The first is the example of Myriad Genetics Inc, Salt Lake City, UT, USA, which has patented the genetic diagnostic test for the BRCAl and BRCA2 breast cancer mutations in the US and, to a lesser extent, in Europe. It is enforcing its patent rights to require national healthcare systems to pay its highly increased fee to conduct the test in Atlanta, when hospitals can perform the test locally much more cheaply and efficiently. Many, including the Curie Institute, which is spearheading opposition proceedings at the European Patent Office, argue that allowing such technologies to be patented undermines socialised healthcare regimes, inadvertently leading to privatisation and diminished access to healthcare. Many women have not been able to access the test due to its high cost.
A second well known example concerns access in developing countries to life saving drugs that are used to treat and prevent the transmission of diseases, in particular AIDS. One of the most high profile instances of this struggle was the ruling in 2001 by the South African Constitutional Court against the Pharmaceutical Manufacturer's Association, allowing the generic substitution of medicines, parallel importation of patented medicines, and requiring a transparent medicine pricing system in that country. ${ }^{1}$ Over 60 developing countries have lobbied for a "public health" necessity exception to the provisions of TRIPS. ${ }^{2}$ TRIPS requires developing countries to adopt a 20 year minimum of patent protection for pharmaceuticals. Such claims against the rigid operation of the patent regime in healthcare matters are supported by the increasingly recognised right to healthcare (included in a wide range of international treaties* ${ }^{*} 60$ national constitutions, ${ }^{3}$ and decisions of national courts $^{4}$ ) and the evidence that the existence of patent laws often impedes access to vital medicines. Thus there is a growing recognition in the international and domestic context that the patent system may not function well for the equitable and affordable delivery of healthcare goods, and its strict operation may have to be altered by enacting accompanying regulation or changing patent laws themselves. Our available evidence therefore indicates that patenting medical advances often erects formidable barriers to their access, particularly for people in the developing world.

Asserting that the "patenting of such treatment does not decrease the availability of healthcare and does not create new obstacles, different from those already existing in the medical world" adopts a developed world perspective on intellectual property law and the provision of healthcare. It forgets the majority of the world's population living in poverty and subject to the trade whims and norms of developed nations. It also ignores the globalised, harmonised, and international nature of intellectual property law, where local changes in the laws of developed countries have a huge impact on the international content and definition of intellectual property law. Of particular concern is requiring developing countries to adopt standards that may be inappropriate to encourage innovation and development of healthcare technologies at their stage of political, social, and economic development, or pointing out the well known fact that many developed countries adopted patent laws only after reaching a certain stage of economic and social development. ${ }^{5}$ The "consistency and logic of the law" should not prevail over broader distributional and equity concerns.

\section{THE PATENT SYSTEM}

The second problem, following from the above, is the palpable lack of proof for and the inherent pro patent focus of the authors' assertions. Patenting is not a right; it is a privilege, a grant of a property and exclusive monopoly right, valid for two decades with potential for international scope and enforcement. The authors' assertions rest on an allocation of risk that places the greatest risk on society rather than on the inventor. As they claim: "While there is no empirical data to prove either of the competing policy, the authors believe that prohibition of medical methods patents may well discourage innovation". They advocate a precautionary principle, which would dictate that in the absence of any proof that the patent system does or does not spur innovation, it is safest to patent in order to encourage innovation.

*Including the International Covenant on Economic, Social, and Cultural Rights (Article 12(1)) and the Convention on the Rights of the Child (Article 24). See also regional instruments including the Banjul Charter (Article 17), the European Social Charter (Article 11(3)) and the American Declaration of the Rights and Duties of Man (Article 17). 
With respect, this approach seems reckless given the pressing public health and access concerns to medical methods of treatment outlined above. A truly precautionary principle would only grant a 20 year monopoly when it is proven that the patent system does in fact encourage innovation in industry specific fields, particularly in the field of medical methods. This conclusion is supported by the recent report of the Commission on Intellectual Property Rights to the UK government, authored by patent experts from the developed and developing world as well as a Senior Director at Pfizer. ${ }^{6}$ It held that "[p]atenting and licensing should only be undertaken where it is judged necessary to encourage private sector development and the application of technologies."

It has yet to be proved that only patents provide the appropriate incentives, particularly through the promise of compensating for costly $R \& D$, to encourage socially useful innovation across industries, or specifically in the area of medical methods. The correlation between patents, incentives, and innovation is contested and unclear. ${ }^{7}$ The only strong conclusion emerging from the literature is that determining whether patents provide an incentive to innovate depends on a close analysis of industry and country specific factors, looking to such variables as the size of market players, market structure, and the distribution of public and private research costs. ${ }^{7}$ There are powerful arguments that encouraging innovation and technological development may be better served by schemes outside the patent law, including government buyouts, auctions, R\&D tax credits, ${ }^{8}$ and investing in education. ${ }^{9}$ There is even evidence that in certain industries (particularly biotechnology) patents are used to slow innovation, by collecting many patents of similar scope to block future discoveries by competitors. ${ }^{10}{ }^{11}$ My main point is that it is not a truth that patents stimulate invention, particularly in the area of medical methods. To argue persuasively about incentives requires subtle economic analysis of medical treatment innovators that has just not been conducted.

\section{INTERNATIONAL TRENDS}

Thirdly, while the economic justifiability of the authors' argument is unknown, the consensus or trend in international law is towards creating or strengthening medical methods exceptions to patentability. This trend is significant in part because of the increasingly globalised nature of intellectual property law discussed above. While Australia has departed from the medical methods exception in the Bristol-Myers case, ${ }^{12}$ the most patent friendly country in the world (the United States) has recently legislated its own form of a medical methods exception, and is considering a similar genetic medical tests and procedures exception from patentability. In 1996 the US passed legislation holding that no damages or injunctive relief would be granted against a medical practitioner patent infringer for the patenting of a medical or surgical procedure performed on a body. ${ }^{13}$ Thus, instead of prohibiting the patenting of medical methods, the US limited the enforcement of the patentee's rights. Recently, Democratic Representative Lynn Rivers introduced a Bill entitled the Genomic Research and Diagnostic Accessibility Act of 2002 into the House of Representative ${ }^{14}$ which would exempt "genetic diagnostic, prognostic, or predictive test[s] or a medical or surgical procedure" from patent infringement remedies against medical practitioners. ${ }^{15}$ In fact, the state of the law in Australia is more of an exception, as it is the only common law country in the Commonwealth that clearly does not have some form of a medical treatment exception from patentability and whose Patent Office allows medical treatment patents (unlike New Zealand).
The authors, further, rely on an "historical accident" argument to explain the continued existence of the medical methods exception in UK and then EU law. The authors contend that a legislated medical methods exception arose in both Parliaments from the failure of a British Parliamentary Committee report ${ }^{16}$ to accept the comments of some courts and allow the patenting of medical methods. This interpretation is problematic. Firstly, it ignores the primacy of democratically elected parliaments legislating in areas of complex socioeconomic policy, such as healthcare and regulation of technology and innovation. It implicitly asserts the superiority of courts and their decisions in the law making process and negates that a parliamentary committee can, after considering the broad policy implications and public opinion, recommend other than what the judiciary have suggested. Without any proof or basis in legislative records, the authors speculate that without the report Parliament would have allowed medical treatments to be patented. In fact, White asserts there was political pressure at the time of that legislation to curb patenting in the field of medicine. ${ }^{17}$

Secondly, the preparatory documents to the European Patenting Convention (EPC) demonstrate that excluding medical methods was the product of a well debated consensus between European states, many of whom, as the authors acknowledge, had medical methods exceptions to patentability in their laws. It was the need to balance these interests, rather than the Banks Committee report, that determined the shape of the medical methods exception.

\section{THE JUSTIFICATION}

The fourth point moves from the more general and structural considerations just discussed to the specific nature and justifications for a medical methods exception. Medical methods, as defined by the patent law, form a specialised niche of otherwise patentable medical technologies, such as medical devices (electrocardiograms (ECG), magnetic resonance imaging (MRI) and so on), drugs, and cosmetic treatments. Medical methods are unique because generally they are used directly by doctors in the course of medical treatment and diagnosis. Thus, from a historical analysis as well as from current judicial and political interpretations, the medical methods exception plays an important role in protecting and preserving medical professional solidarity, which arguably leads to high quality medical care and technological progress. The judicial and academic failure to acknowledge this underlying "golden thread" of justification explains many of the inconsistencies and weak arguments in the law that the authors highlight. Debating whether the law should continue to support a medical treatment exception should ask whether our existing patent law most effectively protects the medical profession in providing optimal healthcare. Only by understanding how a medical treatment exception fits in the complex web of trade, health, and professional regulation can one properly assess whether it should be retained or discarded.

The medical exception from patent law arose in the UK in the late 1800s concurrently with the drive to professionalise medicine and at the height of the abuse of the patents regime by dangerous "patent medicines", although this exception was not recognized by the courts until $1914 .^{18}$ Through the 1800 s and early 1900s the BMJ and the Lancet documented the continuing struggle of medical doctors to secure a professional income by controlling medical service provision, training and inventions. Doctors had to be (and be perceived to be) free from the taint of market commerce and trade, in part because of the conflicts of interest this could generate between their financial interests and their patients' interests. ${ }^{19}{ }^{20}$ However, as these documents also show, professional 
self-regulation required a sense of professional solidarity and an image of competence, which led to internal dispute and resolution regimes removed from lawyers. Finally, the medical profession felt that defining best medical knowledge and practice should occur through introduction and vetting at free and open public lectures, collegial training, group discussion, and publication in the profession's journals.

Patenting methods of treatment conflicted with most of these goals. The association of patents with patent medicines undermined medical credibility, and the purpose of patents was clearly trade regulation, profit, and market control. Allowing doctors to patent medical methods could lead to public fights, thus undermining their authority; this justification has prevailed to the present. While patents could disseminate innovation, the medical profession had its own tailored system of information evaluation and delivery. Focusing on medical methods was intentional as they most clearly represented inventions that would be created and applied by doctors, as opposed to pharmaceutical inventions, for example, that would be manufactured by outside firms. ${ }^{21}$ The extent to which this justification remains useful should be discussed in light of the original purposes for its creation, querying whether those original purposes remain valid given the changing structure of the medical profession and healthcare provision, as well as developments in technology.

\section{CONCLUSION}

In considering whether methods for medical treatment should be patentable we must look to reality-historical and current, domestic and international-to objectively assess the impact and purposes of patent laws. We must also consider the data and where none exist, proceed very cautiously, particularly where human rights such as the rights to life, health, the rights to the benefits of scientific progress might be affected. Only after careful, contextual, and multiparty discussion and analysis should any alteration in the state of the law even be considered.

T Piper

Department of Law, University of Oxford, Oxford, UK; tina.piper@gmail.com

\section{REFERENCES}

1 Treatment Action Campaign. The Medicines Act Court Case, Available at http://www.tac.org.za/Documents (accessed 27 August 2004).

2 World Trade Organization. Agreement on Trade-Related Aspects of Intellectual Property Rights (adopted 15 April 1944) 33 ILM 81.

3 Hunt P. The Right of Everyone to the Highest Attainable Standard of Physical and Mental Health, Report of the Special Rapporteur submitted in accordance with Commission Resolution 2002/31.

4 Treatment Action Campaign. Minister of Health et al $v$ Treatment Action Campaign et al, Available at http://www.tac.org.za/Documents (accessed 27 August 2004).

5 Chang HJ. Kicking Away the Ladder. London: Anthem, 2001; Patents, International Trade Law and Access to Essential Medicines, Available at http://www.aidslaw.ca/Maincontent/issues/cts/selectedresources.htm (accessed 27 August 2004).

6 Commission on Intellectual Property Rights. Integrating Intellectual Property Rights and Development Policy, London, 2002.

7 Dixon P, Greenhalgh C. The Economics of Intellectual Property: A Review to Identify Themes for Future Research. Oxford: Oxford Intellectual Property Research Centre, (Available at: http://www.oiprc.ox.ac.uk).

8 Griffith R. How important is business R\&D for economic growth and should the government subsidise it? Briefing Note 12. The Institute for Fiscal Studies, 2000.

9 Romer P. Should the government subsidize the supply or demand in the market for scientists and engineers? Working Paper w 7723. National Bureau of Economic Research, 2000.

10 Gangi M. Competition Policy and the Exercise of Intellectual Property Rights. Working Paper LUISS, 1999. Available at http://www.archivioceradi.luiss.it/ osservatori/intellettuale (accessed 3 September 2004).

11 Shapiro C. Competition Policy and Innovation, STI Working Paper 2002/11.

12 Australian Law Reform Commission Gene Patenting and Human Health (ALRC Sydney 2004) Proposal 7-2.

1335 USC § $287(C)$.

14 US House of Representatives 3967 107th Congress (2002). Available at http://thomas.loc.gov (accessed 3 September 2004).

$15 \mathrm{~S} 271(3)(\mathrm{a})$. The full text of the Bill and related documents are available at, Democratic Caucus, Committee on Science http://www.house.gov/ science_democrats/member/lr031402.htm.

16 Banks MAL. The British Patent System: Report of the Committee to Examine the Patent System and Patent Law, Banks Committee Report.HM Stationery Office Cmnd 4407, 1970.

17 White AW. Patentability of Medical Treatment, Wellcome Foundation's (Hitching's) Application, EIPR November, 1980.

18 C\&W's Application (1914) 31 RPC 235.

19 British Medical Association. Patents by Medical Men [1903] BMJ 1242 1242.

20 British Medical Association. Central Ethics Committee Minutes 1929-30: index 10, Research and Inventions Subcommittee Meeting, Wednesday October 23rd 1929. Revised Memorandum Submitted by the Association of British Chemical Manufacturers for Submission to the Board of Trade Patents Committee. 1: indices 2, 8, 11, and 39).

21 British Medical Association. Central Ethics Committee Minutes 1929-30. 